\title{
PEACEBUILDING AND RECONCILIATION CONTEMPORARY THEMES AND CHALLENGES
}

Marwan Darweish and Carol Rank (eds)

London: Pluto Press

2012, 228 pages

ISBN 0745332888 Paperback

ISBN 9780745332888

It is said that the reader of any book brings his or her own reality to that book, which then generates a new, richer reality. This book review of Peacebuilding and reconciliation: Contemporary themes and challenges has been written from the Centre for Trust, Peace and Reconciliation (CTPSR), Coventry University, by a South African. Ruins and reconstructions in Coventry city speak of the destruction of war and conflict over centuries. They also speak of the potential for peacebuilding and reconciliation against severe odds, of a city rising from the ashes - and not just rebuilding, but reinventing itself for the greater good, thus going beyond reconciliation. This town's history as recorded formally and living in the minds of people, statues, living monuments and current practices, most notably its rich global ethnic diversity and related ways of life, reveal the human drive to forgive, reconcile and prosper in peace in spite of, and in the case of the CTPSR, one of its living monuments, because of its diversity.

The reviewer's spatial orientation above is contextualised by a publication that manages to combine scholarly insights with lived experiences of the complexities of conflict around the globe. Through Peacebuilding and reconciliation: Contemporary themes and challenges, a rich ethnic and scholarly diversity of authors contemplate critically what constitutes peace and peacebuilding and contextual reconciliation. They challenge existing definitions of peace, security, home, and many other definitions which are often found contextually inadequate.

Scientia Militaria, South African Journal of Military Studies, Vol 43, No. 1, 2015, pp. 164-167. doi : $10.5787 / 42-1-1116$
They also reveal which challenges to security remain.

The text is divided into four themes:

- Peace: but what kind of peace? 
- Reconciliation and dealing with the past

- Cultural processes and initiatives

- Challenges to peacebuilding and reconciliation.

Contributions include critical case studies relating to diverse and often interconnected peacebuilding and reconciliation opportunities, threats, successes and challenges from places as diverse as Afghanistan, Kosovo, Ethiopia, the Democratic Republic of the Congo (DRC), Sierra Leone, Canada, Nepal and Palestine. This publication contemplates critical contemporary issues such as liberal peace, sustainable peace and democracy, ethnic conflict and secessionism, indigenous commemorative practices towards reconciliation, post-colonial apology and restitution, interreligious peacebuilding dialogue, the role of health in peacebuilding, the new economy of terror by Islamist insurgencies, repatriation and justice for those remaining in exile, and homecoming of former child soldiers. The experientially rich and scholarly critical accounts and perspectives do not allow their readers to be passive participants or cold observers of the peace and reconciliation phenomenon.

For the purpose of this review, Chapter 5 is singled out. This chapter, "Remembering the past and reconciling for the future: The role of indigenous commemorative practices in Sierra Leone" has contextual relevance to many countries, inter alia post-colonial, post-apartheid South Africa. The author, Steven Kaindaneh quotes Bishop Tutu, respected symbol of South Africa's much-revered and often duplicated Truth and Reconciliation Commission (TRC) as concluding evidence that the indigenous conflict resolution approach 'seeks to rehabilitate both the victim and the perpetrator'. ${ }^{1}$ South Africa, excluded from the case studies in this book, serves as an example of how even a successful TRC does not equate perfect rehabilitation, final peace attained or social justice restored.

This chapter then relates the various objects, programmes and activities that constitute a collective approach to reconciliation in Sierra Leone. Kaindaneh states, "while much attention has been given to formal and state-sanctioned initiatives, very little" is known about how "ordinary people ... commemorate traumatic events" of the past. ${ }^{2}$ While the emphasis here is on "rural African communities", ${ }^{3}$ Kaindaneh's contribution challenges all communities within all countries from both ends of the socio-political divide to position themselves within their own particular and diverse reconciliatory objects, programmes and activities and to assess critically whether those that should participate in order to contribute to reconciliation and lasting peace, indeed do so. And if they do, they should question whether the level of participation from those previously and still favoured by oppression is sufficient to bring about forgiveness, reconciliation and lasting peace. 
This book moves one to reflect on threats to peace and reconciliation in one's own country and elsewhere. In South Africa currently, shops owned by foreigners, many of whom made arduous journeys away from conflict in their countries of origin, are attacked; local youths loot shops with scant regard for police presence; the redistribution of land remains unresolved on the reconstruction of social justice agenda, so too, equity in sport and education at all levels; the nonrelease of apartheid criminals on bail is challenged against the release of other political criminals; women remain extremely vulnerable as targets of rape and other forms of abuse, et cetera. Peacebuilding and reconciliation: Contemporary themes and challenges confirms through richly presented case studies that peace is a multilayered objective, not an achievable end, that layers of peace already attained are often fragile, and that reconciliation demands active participation in social justice reform. It also confirms that reconciliation demands reciprocal willingness to concede in direct proportion to possession of various pre-reconciliation positions and spheres of power. It challenges, as TRC champion Bishop Tutu in his foreword to Reconciliation after violent conflict suggests, both society and individuals of affected countries to "discover their own routes to reconciliation". ${ }^{4}$

I intentionally refrain from offering negative criticism. Fundamental disagreement lies at the heart of any conflict. Therefore, there are likely to be opposing views about the content of even scholarly accounts of any such conflict too. The authors of Peacebuilding and reconciliation: Contemporary themes and challenges, being serious scholars in the field of reconciliation and peacebuilding, would be rather unlikely to either justify or mitigate any particular viewpoint wittingly. Their accounts should rather serve as catalysts for objective reflection of any other conflict experienced by any of the publication's readers. Peacebuilding and reconciliation: Contemporary themes and challenges is recommended for peace, reconciliation and social justice scholars and practitioners alike, and every global citizen who subscribes to the principle that "an injury to one is an injury to all". 5

Dr Gerhard van Zyl, Stellenbosch University

\section{Endnotes}

${ }^{1}$ Kaindaneh, S. 2012. Indigenous commemorations in Sierra Leone. In Darweish, M $\&$ Rank, C (eds). Peacebuilding and reconciliation: Contemporary themes and challenges. London: Pluto Press, 79.

${ }^{2}$ Ibid., p. 72

${ }^{3}$ Ibid., p. 72 
${ }^{4}$ Foreword by honourable Archbishop Desmond Tutu to Bloomfield, D, Barns, T \& Huyse, L. Reconciliation after violent conflict: A handbook. Sweden:

International Institute for Democracy and Electoral Assistance, 2003.

${ }^{5}$ A motto popularised by the Industrial Workers of the World (IWW). 